\title{
Perlindungan Hukum Terhadap Pihak Ketiga Atas Perjanjian Perkawinan Yang Dibuat Setelah Perkawinan
}

\author{
Yudiana Dewi Prihandini \\ Magister Kenotariatan Hukum Universitas Islam Indonesia \\ Jl. Cik Di Tiro No. 1 Yogyakarta \\ yudianadewiprihandini@gmail.com
}

\begin{abstract}
This study aims to formulate legal protection efforts for third parties if the marriage agreement is made after the marriage. This is derived from the Constitutional Court Decision Number 69 / PUU-XII / 2015 that defines the marriage agreement to be expandable, so that the marriage agreement is no longer interpreted only as an agreement made before the marriage (prenuptial agreement) but can also be made after the marriage takes place (postnuptial agreement). The Constitutional Court's decision can lead to legal problems and legal uncertainty for third parties. This relates to the execution carried out by the creditor in the event of an agreement to separate property and unclear parties responsible when there is a default. This research is a normative legal study with the statutory and case approach. This study concludes, firstly, the Constitutional Court Decision Number 69 / PUU-XII / 2015 regarding marriage agreements can lead to rights and obligations and consequences for the parties. Second, in order to guarantee legal protection for third parties, the making and amendment of the marriage agreement should be carried out before a notary, made in good faith by the parties, must be recorded by the marriage registrar.
\end{abstract}

Keywords: Legal protection; marriage agreement; third party

\begin{abstract}
Abstrak
Penelitian ini bertujuan merumuskan upaya perlindungan hukum bagi pihak ketiga apabila perjanjian perkawinan dibuat setelah perkawinan. Hal ini ditengarai pascaPutusanMahkamah Konstitusi Nomor 69/PUU-XII/2015makna perjanjian perkawinan diperluas,sehingga perjanjian perkawinan tidak lagi dimaknai hanya sebagai perjanjian yang dibuat sebelum perkawinan (prenuptial agreement) tetapi juga bisa dibuat setelah perkawinan berlangsung (postnuptial agreement). Putusan MK ini dapat menimbulkan masalah hukum serta ketidakpastian hukum bagi pihak ketiga. Hal ini berkaitan dengan eksekusi yang dilakukan oleh kreditor apabila terjadi perjanjian pisah harta dan ketidakjelasan pihak yang bertanggungjawab ketika terjadi wanprestasi. Penelitian ini merupakan penelitian hukum normatif denganpendekatan perundang-undangan (statute approach) dan pendekatan kasus (case approach). Penelitian ini menyimpulkan, pertama,Putusan Mahkamah Konstitusi Nomor 69/PUU$\mathrm{XI} / 2015$ tentang perjanjian perkawinan dapat menimbulkan hak dan kewajiban serta konsekuensi bagi para pihak.Kedua, agar dapat menjamin perlindungan hukum bagi pihak ketiga maka pembuatan dan perubahan perjanjian perkawinan diupayakan dilakukan dihadapan Notaris, dibuat dengan itikad baik para pihak, wajib dicatatkan oleh petugas pencatat perkawinan.
\end{abstract}

Kata-kata Kunci : Perjanjian perkawinan; perlindungan hukum; pihak ketiga 


\section{Pendahuluan}

Setiap rumah tangga yang dibentuk memiliki tujuan untuk kehidupan yang lebih baik bagi keduanya, akan tetapi keinginan tersebut tidak selalu sesuai dengan harapan. Suatu perselisihan baik besar maupunkecil potensi terjadi pada sebuah rumah tangga. Perselisihan dapat berakhir dengan baik atau justru menimbulkan perceraian. Faktor-faktor yang mempengaruhi perceraian misalnya, beban tanggung jawab, perkawinan di bawah umur, moral, menyakiti jasmani atau kekerasan dalam rumah tangga (KDRT), cacat biologis, adanya perselisihan terus menerus, dan perbedaan keyakinan. ${ }^{1}$ Angka perceraian di Indonesia sepanjang 2018 tercatat sebanyak 419.268. ${ }^{2}$ Perselisihan yang memicu perceraian rentan menimbulkan persoalan hukum antara kedua belah pihak (suami-istri), utamanya mengenai harta benda. Terlebih bagi pasangan yang tidak membuat perjanjian sebelum perkawinan atau pada saat berlangsungnya perkawinan, atau pasca perkawinan mengenai harta benda keduanya.

Putusan Mahkamah Konstitusi Nomor 69/PUU-XIII/2015 merupakan sebuah solusi bagi pasangan suami istri yang belum membuat perjanjian perkawinan, berencana akan membuat perjanjian perkawinan ataupun mengubah perjanjian perkawinan yang telah dibuat ditengah perjalanan perkawinan. Bahkan mencabut perjanjian perkawinan mereka apabila kedua belah pihak menghendaki, sebagai proteksi terhadap harta benda apabila suatu saat terjadi hal yang tidak diinginkan seperti perceraian. Akan tetapi, hal tersebut menimbulkan dimensi baru baik terhadap akibat hukum harta benda perkawinan, kepastian hukum bagi pihak ketiga dan dapat menimbulkan permasalahan kepemilikan hak atas tanah yang berkaitan dengan suami istri yang berbeda kewarganegaraan.

Putusan tersebut bermula dari gugatan Ike Farida, dengan Perkara Nomor 69/PUU-XIII/2015, mengenai kasusnya yang merasa hak-haknya sebagai warga Indonesia yang terenggut akibat pernikahannya dengan Warga Negara Asing yang

\footnotetext{
1 "Tingginya Angka Perceraian Di Yogyakarta Menjadi Perhatian KPP” dalam http://www.dprddiy.go.id/tingginya-angka-perceraian-di-yogyakarta-menjadi-perhatian-kpp/ Akses 23 November 20152 https://putusan.mahkamahagung.go.id/ Akses 3 April 2019

2 https://putusan.mahkamahagung.go.id/ Akses 3 April 2019
} 
tidak disertai perjanjian pisah harta dengan suaminya. Ike Farida dalam gugatannya merasa terdiskriminasi, tidak mendapatkan hak konstitusionalnya sebagai warga negara Indonesia karena perkawinannya dengan warga negara asing. Nyonya Ike Farida tidak dapat memiliki hak milik maupun hak guna bangunan seumur hidupnya selama berstatus sebagai istri dari warga negara asing. Hal ini dikarenakan, sebagaimana diatur dalam Pasal 35 ayat (1) dan 36 ayat (1) UU Perkawinan, seorang perempuan yang kawin dengan warga negara asing dilarang untuk membeli tanah dan atau bangunan dengan status Hak Guna Bangunan.

Pasca putusan MK Nomor 69/PUU-XIII/2015, Pasal 29 ayat (1) UU Perkawinan berubah menjadi "Pada waktu, sebelum dilangsungkan atau selama dalam ikatan perkawinan kedua pihak atas persetujuan bersama dapat mengadakan perjanjian tertulis yang disahkan oleh pegawai pencatat perkawinan atau notaris, setelah mana isinya berlaku juga terhadap pihak ketiga sepanjang pihak ketiga tersangkut." Putusan tersebut telah memperluas makna perjanjian perkawinan sehingga perjanjian perkawinan tidak lagi dimaknai hanya sebagai perjanjian yang dibuat sebelum perkawinan (prenuptial agreement) tetapi juga bisa dibuat setelah perkawinan berlangsung (postnuptial agreement). Sehingga, pasca putusan ini, WNI seperti Ike Farida yang belum membuat perjanjian sebelum perkawinan, dapat membuat perkawinan pasca perkawinan berlangsung, guna melindungi hak konstitusionalnya.

Namun demikian, putusan Mahkamah Konstitusi Nomor 69/PUU-XIII/2015 ini dapat menimbulkan masalah hukum dikemudian hari serta ketidakpastian hukum bagi pihak ketiga. Hal ini berkaitan dengan eksekusi yang dilakukan oleh kreditor apabila terjadi perjanjian pisah harta dan ketidakjelasan pihak yang bertanggungjawab ketika terjadi wanprestasi. Persoalan ini dapat timbul karena ada peluang bagi suami atau istri yang belum membuat perjanjian perkawinan pisah harta dapat membuat perjanjian perkawinan selama perkawinan mereka, sedangkan harta bendanya telah terikat pada perjanjian kredit harta.

\section{Rumusan Masalah}

Menimbang uraian permasalahan hukum di atas, maka rumusan masalah dalam penelitian ini adalah, pertama, implikasi putusan Mahkamah Konstitusi Nomor 69/PUU-XIII/2015 terhadap tindakan pembuatan dan perubahan 
perjanjian perkawinan? Kedua, bagaimana perlindungan hukum bagi pihak ketiga apabila perjanjian perkawinan dibuat setelah dilangsungkannya perkawinan?

\section{Tujuan Penelitian}

Tujuan dari penelitian ini adalah untuk terlebih dahulu menganalisis implikasi putusan Mahkamah Konstitusi Nomor 69/PUU-XIII/2015 terhadap tindakan pembuatan dan perubahan perjanjian perkawinan, kemudian merumuskan upaya perlindungan hukum bagi pihak ketiga apabila perjanjian perkawinan dibuat setelah dilangsungkannya perkawinan.

\section{Metode Penelitian}

Penelitian ini merupakan penelitian hukum normatif dengan pendekatan penelitian yang digunakan adalah pendekatan perundang-undangan (statute approach) dan pendekatan kasus (case approach). ${ }^{3}$ Bahan hukum dalam penelitian ini bahan hukum primer yang terdiri dari bahan-bahan hukum yang mempunyai kekuatan mengikat sebagai landasan utama yang dipakai dalam rangka penelitian ini, yang terdiri dari: Kitab Undang-Undang Hukum Perdata, UU Perkawinan Nomor 1 Tahun 1974, Peraturan Pemerintah Pelaksana Republik Indonesia Nomor 9 Tahun 1975 tentang Pelaksanaan UU Nomor 1 Tahun 1974, Kompilasi Hukum Islam, Undang-Undang Nomor 22 Tahun 1046 tentang Pencatatan Nikah, Nikah, Talak, dan Rujuk, Putusan Mahkamah Konstitusi Nomor 69/PUU/-XIII/2015, serta peraturan-peraturan lain yang berkaitan dengan perjanjian perkawinan dan bahan hukum sekunder yakni bahan-bahan yang erat hubungannya dengan bahan hukum primer dan dapat membantu menganalisis dan memahami bahan hukum primer, seperti buku-buku dan diktat-diktat literatur tentang perdata atau perkawinan, hasilhasil penelitian, hasil seminar, hasil karya dari kalangan hukum, serta dokumendokumen lain yang berkaitan dengan perjanjian perkawinan. ${ }^{4}$

Teknik pengumpulan bahan hukum yang dilakukan dalam penelitian ini adalah dengan penelitian kepustakaan (library research) yang dilakukan dengan

3 Peter Mahmud Marzuki, Penelitian Hukum, Kencana, Jakarta, 2009, hlm. 22.

${ }^{4}$ Suratman dan h. Philips Dillah. Metode Penelitian Hukum, Cetakan Kesatu, Alfabeta, Bandung, 2013, hlm. 51 
pengumpulan data sekunder melalui penelusuran literatur kepustakaan, peraturan perundang-undangan, penetapan pengadilan, buku-buku, karya ilmiah, artikel, majalah/jurnal hukum, dan sumber lainnya yang terkait. Penelitian ini menggunakan analisis kualitatif, dengan langkah berpikir sistematis, bahan hukum primer dianalisis dengan menggunakan langkah-langkah normatif dan kemudian dilanjutkan pembahasan dengan secara analisis desktiptif.

\section{Hasil Penelitian dan Pembahasan}

\section{Implikasi Putusan MK No. 69/PUU/XII/2015 terhadap tindakan Pembuatan dan Perubahan Perjanjian Perkawinan}

Salah satu akibat hukum dari perkawinan adalah terciptanya harta benda perkawinan, yaitu harta bersama dan harta pribadi, berdasarkan Pasal 35 ayat (1) UU Nomor 1 Tahun 1974 tentang Perkawinan, Harta bersama suami-istri hanyalah meliputi harta-harta yang diperoleh suami-istri sepanjang perkawinan maka dapat disimpulkan bahwa yang masuk dalam harta bersama adalah hasil dan pendapatan baik suami maupun istri. Sedangkan harta pribadi menurut Pasal 35 ayat (2) UU Nomor 1 Tahun 1974 tentang Perkawinan, adalah Harta yang sudah dimiliki atau harta bawaan suami atau istri pada saat perkawinan dilangsungkan dan harta benda yang diperoleh masing-masing sebagai hadiah atau warisan tidak masuk ke dalam harta bersama kecuali mereka memperjanjikan lain. Harta pribadi tersebut masih dapat dibedakan lagi yaitu harta bawaan suami atau istri yang bersangkutan, juga harta yang diperoleh suami atau istri sebagai warisan, hadiah, maupun hibah.

Wujud dan ruang lingkup harta bersama tidak diuraikan secara lebih lanjut dalam undang-undang perkawinan, akan tetapi kaidah hukum bahwa semua harta yang diperoleh selama masa perkawinan menjadi yurisdiksi harta bersama telah tertanam. ${ }^{5}$ Proses peradilan pada dasarnya mengembangkan semua harta yang diperoleh selama ikatan perkawinan menjadi yurisdiksi harta bersama dalam proses peradilan. Berdasarkan pengembangan tersebut maka, suami dan istri memiliki kedudukan yang sama dalam harta bersama, yaitu dapat bertindak atas persetujuan kedua belah pihak sesuai yang diatur dalam Pasal 36 ayat (1) UU Perkawinan. Maka dari ketentuan itu lahirlah tanggung jawab dari suami dan

${ }_{5}$ Abdul Manaf, Aplikasi asas Equalitas Hak dan Kedudukan Suami Istri dalam Penjaminan Harta Bersama pada Putusan Mabkamah Agung, CV. Mandar Maju, Bandung, 2006, hlm. 46. 
istri ketika mereka secara perjanjian perkawinan dibuat dalam bentuk tertulis baik dibawah tangan maupun otentik. Perjanjian perkawinan yang dibuat dalam bentuk di bawah tangan dapat diajukan untuk disahkan oleh Pegawai Pencatat Perkawinan atau notaris sesuai yang tertera dalam Putusan MK mengenai perluasan makna ketentuan Pasal 29 ayat (1) UU Perkawinan. Perjanjian perkawinan memiliki beberapa jenis, sebagai berikut:

1. Percampuran laba dan rugi (gemeenscap van winst en verlies) yaitu seluruh pendapat yang diterima suami istri yang didapatkan secara cuma- cuma (hibah atau warisan) dan penghasilan yang mereka terima akan menjadi milik bersama begitu pula semua kerugian atau pengeluaran menjadi tanggungan bersama.

2. Percampuran penghasilan (gemeenschap van vruchten en inkomsten) yaitu yang terjadi dalam perjanjian ini hanya persatuan penghasilan saja. Penghasilan yang diterima oleh masing-masing pihak menjadi harta bersama tetapi untuk pengeluaran atau kerugian yang diperoleh ditanggung oleh masing-masing pihak.

3. Pemisahan harta secara bulat (keseluruhan) yaitu pemisahan seluruh harta, baik harta sebelum maupun sepanjang perkawinan berlangsung menjadi hak dari masing-masing, dengan pemisahan harta secara sepenuhnya inilah, suami dan istri tersebut bisa melakukan perbuatan hukum sendiri atas hartanya tanpa perlu mendapatkan persetujuan dari suami ataupun istrinya.

Jenis-jenis perjanjian perkawinan menurut KHI Pasal 45 adalah sebagai berikut :

1. Ta'lik talak menurut ketentuan Pasal 1 huruf (e) KHI adalah Perjanjian yang diucapkan calon mempelai pria setelah akad nikah yang dicantumkan dalam akta nikah berupa janji talak yang digantungkan kepada suatu keadaan tertentu yang mungkin terjadi pada masa yang akan datang.

2. Perjanjian lain yang tidak bertentangan dengan hukum Islam, suami atau istri dapat mengajukan persoalannya ke Pengadilan Agama apabila salah satu pihak tidak memenuhi perjanjian yang telah disepakati keduanya. Istri berhak meminta pembatalan nikah atau sebagai alasan perceraian dalam gugatannya apabila suami melanggar perjanjian, dan juga sebaliknya apabila istri yang melanggar perjanjian di luar taklik talak, maka suami berhak mengajukan perkaranya ke Pengadilan Agama. ${ }^{6}$ Pasal 47 ayat (2) disebutkan bahwa, perjanjian perkawinan itu dapat berupa percampuran harta pribadi atau pemisahan harta pencarian masing-masing sepanjang

${ }^{6}$ Ahmad Rofiq, Hukum Islam di Indonesia, Raja Grafindo Persada, Jakarta, 2003, hlm. 162. 
tidak bertentangan dengan hukum Islam. Mengenai bentuk perjanjian perkawinan yang lain yang menyangkut kedudukan harta dalam perkawinan meliputi permasalahan sebagai berikut:

a) Dapat berisi tentang percampuran harta pribadi;

b) Pemisahan harta pendapatan masing-masing suami istri;

c) Kewenangan melakukan pembebanan terhadap harta pribadi dan harta bersama;

d) Perjanjian perkawinan mengenai harta tidak boleh menghilangkan kewajiban suami untuk memenuhi kebutuhan rumah tangganya. Hal ini bertujuan untuk melindungi istri atas hasil pencahariannya.

Dengan membuat postnuptial agreement, maka akan terjadi pemisahan harta kekayaan sesuai dengan kehendak suami dan istri, dengan demikian masingmasing pihak dapat bertanggung jawab atas harta bendanya tanpa bergantung satu sama lain.

Setelah munculnya putusan Mahkamah Konstitusi No. 69/PUU/XII/2015, perjanjian perkawinan dapat dibuat oleh pasangan suami setelah perkawinan berlangsung. Terdapat beberapa situasi yang menjadi alasan dibuatnya perjanjian perkawinan setelah terjadinya perkawinan, lebih rinci adalah sebagai berikut:7

1. Adanya kealpaan dan ketidaktahuan, Undang-undang Nomor 1 Tahun 1974 tentang Perkawinan ada ketentuan yang mengatur tentang Perjanjian Kawin dibuat sebelum pernikahan dilangsungkan.

2. Adanya risiko yang mungkin timbul dari harta bersama. Para pihak memilih untuk bertanggung jawab mengenai harta pribadi masing-masing.

3. Adanya sikap individual. Para suami istri sama-sama tidak mau terlibat dalam permasalahan yang diderita oleh pasangan mereka, karena pengaruh lingkungan dan peradaban manusia yang semakin liberal dan meniru kehidupan barat yang pada akhirnya terbawa oleh pasangan suami-istri untuk melakukan pembuatan Perjanjian Kawin.

4. Adanya keinginan untuk tetap memiliki sertifikat dengan hak milik atas tanah. Warga Negara Indonesia yang menikah dengan Warga Negara Asing tidak dapat memiliki hak milik, hak guna usaha, maupun hak guna bangunan karena adanya harta bersama dalam perkawinan, untuk menyimpangi ketentuan tersebut maka pasangan suami istri beda kewarganegaraan perlu membuat perjanjian perkawinan.

Oleh karena sebab-sebab tersebut, tidak sedikit pula pasangan-pasangan yang kemudian membuat perjanjian perkawinan setelah perkawinan

7 Annisa Istriyanti dan Erwan Priambada. "Akibat Hukum Perjanjian Perkawinan yang dibuat Setelah Perkawinan Berlangsung”, Privat Law Vol. III No 2 Juli-Desember 2015, hlm. 91 
dilangsungkan, akibat pembuatan perjanjian perkawinan dapat ditinjau dari beberapa segi, diantaranya: ${ }^{2}$

1. Perjanjian perkawinan dapat dibuat sebelum perkawinan, pada saat dilangsungkannya perkawinan, maupun pada masa perkawinan;

2. Saat berlakunya perjanjian perkawinan adalah sejak perkawinan dilangsungkan, kecuali ditentukan lain dalam perjanjian perkawinan. Penentuan tanggal berlakunya perjanjian perkawinan sejak perkawinan dilangsungkan untuk perjanjian perkawinan yang dibuat sepanjang perkawinan akan berakibat terhadap harta benda perkawinan yang telah terjadi sebelum perjanjian perkawinan dibuat. Dengan demikian akibat serta kepastian hukumnya terhadap pihak ketiga tergantung pada penentuan kapan berlakunya perjanjian perkawinan;

3. Perjanjian perkawinan dapat diubah maupun dicabut asalkan tidak merugikan pihak ketiga;

4. Supaya berlaku terhadap pihak ketiga, perubahan dan pembatalan perjanjian perkawinan harus pula disahkan oleh pejabat pencatat perkawinan yang tidak jelas dinyatakan di dalam Putusan MK tapi sebaiknya pengesahan tersebut harus dilakukan;

5. Perjanjian perkawinan yang dibuat secara sah berlaku sebagai undangundang dan mengikat para pihaknya, berdasarkan Pasal 1338 KUHPerdata;

6. Terhadap harta benda perkawinan, yaitu: harta benda yang ada sebelum perjanjian kawin dibuat, akan menjadi tanggung jawab bersama, dan harta benda yang diperjanjikan dalam perjanjian kawin, maka hal tersebut akan menjadi tanggung jawab masing-masing sesuai dengan kesepakatan yang dibuat dalam perjanjian kawin tersebut.

7. Terhadap pihak ketiga, perjanjian kawin yang berhubungan dengan pihak ketiga akan berlaku sejak tanggal penetapan Pengadilan Negeri dikeluarkan dan telah dicatatkan oleh Pegawai Pencatat Perkawinan. Sehingga pihak ketiga dalam hal ini tidak dirugikan jika terjadi sesuatu dikemudian hari, karena sudah ada kesepakatan pemisahan harta sebelumnya.

Dibuatnya perjanjian kawin dalam masa perkawinan membawa akibat terhadap perubahan status hukum harta benda serta utang yang terdapat atau diperoleh di dalam perkawinan tersebut yang sangat berkaitan erat dengan pihak ketiga. Dengan demikian seharusnya pembuatan perjanjian perkawinan tersebut tidak boleh merugikan pihak ketiga. Namun demikian, sampai dengan saat ini

${ }^{8}$ Yulies Tiena Masriani, "PerjanjianPerkawinandalam Pandangan Hukum Islam”, Serat Acitya-Jurnal Ilmiah, UNTAG Semarang, hlm. 128 
belum dibuat regulasi yang mengatur tatacara pembuatan perjanjian kawin dalam masa perkawinan sehingga membuka ruang interprestasi secara luas. ${ }^{9}$

Berdasarkan ketentuan Pasal 29 ayat (4) UU No. 1 Tahun 1974 tentang Perakawinan Pasca Putusan MK No. 69/PUU-XIII/2015, maka suami istri dapat menentukan sendiri isi dari perjanjian perkawinan yang akan mereka buat, karena perjanjian perkawinan dapat berisi tentang harta perkawinan atau perjanjian lainnya, asalkan tidak memberatkan atau merugikan salah satu pihak, yang menurut Asser-De Boer, ketentuan tersebut batal demi hukum. ${ }^{10}$ Oleh karenanya ada beberapa hal yang perlu diperhatikan, antara lain:

1. Membuat inventarisasi seluruh harta dan utang suami istri dan harta mana saja yang diperjanjikan dalam perjanjian perkawinan mereka yang kemudian ditanda tangani para pihak dan dilekatkan pada minut;

2. Apabila suatu hari timbul perselisihan mengenai hal yang belum atau tidak diperjanjikan dalam perjanjian, maka akan menjadi tanggung jawab bersama suami istri, dan tidak boleh merugikan pihak ketiga;

3. Ada kemungkinan dimuatnya ketentuan terhadap berlakunya perjanjian perkawinan dengan ketentuan bersyarat demikian pula dengan ketetapan waktu atau termin (termijn);

4. Perjanjian perkawinan hanya berlaku hukum negara Indonesia, dan tidak boleh menggunakan undang-undang negara asing untuk pilihan hukumnya;

5. Tidak boleh mengurangi segala hak disandarkan pada kekuasaan suami dan kekuasaan orang tua, juga hak yang diberikan undang-undang kepada suami-istri yang hidup terlama;

6. Tidak boleh melepaskan hak yang diberikan undang-undang kepada mereka atas harta peninggalan keluarga sedarah mereka dalam garis ke bawah, pun tidak boleh mengatur harta peninggalan itu;

7. Tidak boleh suami istri saling menunjuk sebagai ahli waris masing-masing atau menjanjikan apa yang harus dimuat dalam surat wasiat masing-masing.

\section{Perlindungan Hukum terhadap Pihak Ketiga dalam Pembuatan dan Perubahan Perjanjian Perkawinan}

Sehubungan dengan Putusan Mahkamah Konstitusi No. 69/PUU/XII/2015, apabila para pihak tidak menentukan waktu perjanjian perkawinan mulai berlaku maka akan dimaknai perjanjian perkawinan mulai berlaku terhitung sejak perkawinan dilangsungkan. Jika sebelumnya telah ada perbuatan hukum yang

${ }_{9}$ Candra Hadi Kusuma. "Kedudukan Hukum Perjanjian Perkawinan yang dibuat Setelah Perkawinan terhadap Pihak Ketiga (Pasca Putusan Mahkamah Konstitusi Nomor. 69/PUU-XIII/2015)'. Jurnal Hukum dan Kenotariatan, Vol 2, No 1 (2018): Jurnal Volume II - Nomor 1- Februari 2018. hlm. 176.

${ }^{10}$ C. Asser-J. de Boer, Personen-en Familierecht, Kluwer-Deventer, zestiende druk, 2001, hlm. 301 
berkaitan dengan pihak ketiga, misalnya perjanjian kredit maka perubahan status hukum terhadap harta benda dalam perkawinan yang sebelumnya dalam persatuan bulat menjadi terpisah ini dapat menimbulkan permasalahan hukum. Oleh karena itu, terdapat beberapa hal yang harus diperhatikan serta dilakukan untuk melindungi pihak ketiga dalam pembuatan perjanjian perkawinan yang dibuat setelah terjadinya perkawinan, yaitu:

1. Perjanjian perkawinan harus dibuat dihadapan Notaris

Pembuatan perjanjian perkawinan dihadapan Notaris menjadi penting untuk menjamin kepastian, ketertiban, dan perlindungan hukum. Hal ini berkaitan dengan kebutuhan akan alat bukti tertulis yang bersifat otentik mengenai keadaan, peristiwa, atau perbuatan hukum yang diselenggarakan melalui jabatan tertentu. Notaris merupakan jabatan tertentu yang menjalankan profesi dalam pelayanan hukum kepada masyarakat. Perjanjian perkawinan yang dibuat oleh Notaris dengan prinsip kehati-hatian Notaris dan dengan formilasi akta yangbaik serta edukasi yang diberikan pada para pihaknya, maka isi perjanjian perkawinan tersebut dapat melindungi semua pihak, termasuk pihak ketiga. Prinsip kehati-hatian yang harus dilakukan oleh Notaris sebelum membuat perjanjian perkawinan menurut Habib Adjie, diantaranya:11

a. Mendengarkan serta memahami kehendak para pihak mengenai isi perjanjian perkawinan;

b. Menanyakan hal-hal yang sekiranya perlu untuk ditanyakan, seperti identitas dan dokumen-dokumen kelengkapan, kapan perkawinan dilangsungkan, serta meminta para pihak untuk membuat inventarisasi keseluruhan harta beserta statusnya (sedang menjadi jaminan kredit atau tidak);

c. Mengedukasi para pihak tentang resiko-resiko yang mungkin terjadi atas pembuatan perjanjian perkawinan ini, supaya para pihak beritikad baik dalam pembuatan perjanjian ini;

d. Sebagai proteksi diri dari kriminalisasi Notaris, Notaris dapat membuat atau meminta para pihak untuk membuat pernyataan bahwa semua yang disampaikan para pihak adalah benar;

e. Meminta para pihak untuk membuat pengumuman di media masa, bahwa akan membuat perjanjian perkawinan.

2. Perjanjian perkawinan dibuat dengan itikad baik para pihak

Itikad baik dari para pihak dalam membuat suatu perjanjian merupakan suatu hal yang sangat penting.Terutama hubungannya dengan pihak ketiga, karena hanya suami istri tersebutlah yang mengetahui apabila mereka memiliki perjanjian kredit dengan pihak ketiga yang tidak

11 Wawancara dengan Habib Adjie, Notaris Surabaya, pada tanggal 26 Juli 2019 
diketahui oleh Notaris yang akan membuat perjanjian perkawinan dalam masa perkawinan suami istri tersebut.

3. Perjanjian perkawinan harus dicatatkan pada petugas pencatat perkawinan Pengesahan perjanjian perkawinan merupakan suatu hal yang sangat penting dan tidak boleh dilewatkan oleh suami istri yang membuat perjanjian perkawinan, supaya perlindungan hukum terhadap pihak ketiga terpenuhi serta untuk memenuhi asas Publisitas, seperti yang telah diatur dalam Pasal 29 ayat (1) KUHPerdata jo. Pasal 3 Undang-Undang Perkawinan.

\section{Penutup}

Berdasarkan penelitian yang telah dilakukan oleh penulis, dapat disimpulkan bahwa: Pertama, Putusan Mahkamah Konstitusi Nomor 69/PUU-XII/2015 tentang perjanjian perkawinan menimbulkan hak dan kewajiban serta konsekuensi bagi para pihak, antara lain: (a) perjanjian perkawinan setelah putusan MK dapat dibuat, sebelum, atau dalam masa perkawinan; (b) saat berlakunya sejak perkawinan dilangsungkan maupun dapat ditentukan lain dalam perjanjian, dan mengikat pihak ketiga setelah didaftarkan; (c) dapat diubah maupun dicabut sesuai kesepakatan para pihak, asalkan tidak merugikan pihak ketiga; (d) perubahan dan pembatalan harus disahkan pada petugas pencatat perkawinan agar mengikat pihak ketiga, meskipin belum diatur dalam undang-undang; (e) otomatis mengikat para pihak, sesuai Pasal 1338 KUHPerdata; (f) seluruh harta benda baik harta bawaan maupun harta bersama, menjadi tanggung jawab bersama ataupun masing-masing sesuai kesepakatan dalam perjanjian perkawinan; (g) pembuatan perjanjian perkawinan dalam masa perkawinan harus dicatatkan pada petugas pencatat perkawinan sebagai perlindungan hukum pihak ketiga dan memenuhi asas publisitas.

Kedua, ada beberapa cara yang dapat dilakukan untuk melindungi pihak ketiga atas perjanjian perkawinan yang dibuat pada masa perkawinan, diantaranya: (a) perjanjian perkawinan seharusnya dibuat dihadapan Notaris; (b) Perjanjian perkawinan harus dibuat dengan itikad baik para pihak; (c) Perjanjian perkawinian wajib dicatatkan oleh petugas pencatat perkawinan.

Penelitian ini merekomendasikan kepada Notaris agar pada saat membuat perjanjian perkawian bagi pasangan suami istri yang sudah menikah, terlebih 
dahulu memberikan edukasi mengenai konsekuensi yang akan diterima oleh pasangan suami istri tersebut dikemudian hari, apabila mereka tidak memberikan keterangan dengan jujur mengenai hal-hal yang akan diperjanjikan, serta memformulasikan akta dengan sebaik-baiknya supaya tercipta akta perjanjian perkawinan yang tidak merugikan semua pihak serta pihak ketiga.

Pasangan suami istri yang akan membuat perjanjian perkawinan dalam masa perkawinan, sebaiknya benar-benar menginventarisasi harta mereka dengan baik serta utang-utangnya, dan sebaiknya tidak memasukkan harta-harta dan utangutang yang diperoleh sebelum dibuatnya perjanjian perkawinan kedalam hal yang diperjanjikan, sehingga tetap menjadi tanggung jawab bersama dan meminimalisasi hal-hal yang tidak diinginkan seperti merugikan pihak ketiga.

\section{Daftar Pustaka}

\section{Buku}

Boer, C. Asser-J. de, Personen-en Familierecht, Kluwer-Deventer, zestiende druk, 2001.

J., Sonny Dewi (I), Harta Benda Perkawinan: Kajian Terhadap Kesetaraan Hakdan Kedudukan Suami dan Istri atas Kepemilikan Harta dalam Perkawinan, Refika Aditama, Bandung, 2015.

Manaf, Abdul, Aplikasi asas Equalitas Hak dan Kedudukan Suami Istri dalam Penjaminan Harta Bersama pada Putusan Mahkamah Agung, CV. Mandar Maju, Bandung, 2006.

Marzuki, Peter Mahmud, Penelitian Hukum, Kencana, Jakarta, 2009.

Rofiq, Ahmad, Hukum Islam di Indonesia, Raja Grafindo Persada, Jakarta, 2003.

Suratman dan h. Philips Dillah. Metode Penelitian Hukum, Cetakan Kesatu, Alfabeta, Bandung, 2013.

\section{Internet}

http:/ / www.dprd-diy.go.id/tingginya-angka-perceraian-di-yogyakartamenjadiperhatiankpp/ diakses 23 November 2015.

https:/ / putusan.mahkamahagung.go.id/ Akses 3 April 2019

\section{Jurnal}

Annisa Istriyanti dan Erwan Priambada, "Akibat Hukum Perjanjian Perkawinan yang dibuat Setelah Perkawinan Berlangsung", Privat Law Vol. III No 2 Juli-Desember 2015. 
Candra Hadi Kusuma, "Kedudukan Hukum Perjanjian Perkawinan yang dibuat Setelah Perkawinan terhadap Pihak Ketiga (Pasca Putusan Mahkamah Konstitusi Nomor. 69/PUU-XIII/2015)", Jurnal Hukum dan Kenotariatan, Vol 2, No 1 (2018): Jurnal Volume II - Nomor 1- Februari 2018

Yulies Tiena Masriani, "PerjanjianPerkawinandalam Pandangan Hukum Islam", Serat Acitya-Jurnal Ilmiah, UNTAG Semarang.

\section{Perundang-undangan}

Kitab Undang-undang Hukum Perdata Undang-Undang Nomor 30 Tahun 2004 tentang Jabatan Notaris sebagaimana telah diubah dengan UndangUndang Nomor 2 Tahun 2014 tentang Perubahan atas Undang-Undang Nomor 30 Tahun 2004 tentang Jabatan Notaris menyebutkan bahwa Notaris adalah Pejabat Umum yang berwenang untuk membuat akta otentik dan kewenangan lainnya sebagaimana dimaksud dalam UndangUndang ini.

Undang-Undang nomor 1 tahun 1974 tentang Perkawinan, Lembaran Negara Tahun 1974 Nomor 1, Tambahan Lembaran Negara Nomor 3019.

Peraturan Pemerintah nomor 9 tahun 1975 tentang Pelaksanaan Undang-Undang Nomor 1 tahun 1974 tentang Perkawinan, Lembaran Negara Tahun 1975 Nomor 12, Tambahan Lembaran Negara Nomor 3050.

Kompilasi Hukum Islam, Instruksi Presiden Nomor 1 Tahun 1991 tentang Penyebarluasan Kompilasi Hukum Islam.

\section{Putusan}

Putusan Mahkamah Konstitusi Nomor 69/PUU/-XIII/2015 tentang Perjanjian Perkawinan. 